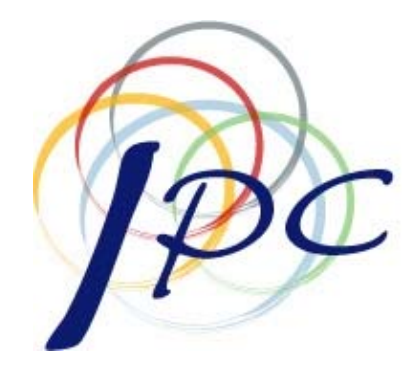

InTERnATIONAL Policy CENTER

Gerald R. Ford School of Public Policy University of Michigan

IPC Working Paper Series Number 70

Are Women More Credit Constrained? Experimental Evidence on Gender and Microenterprise Returns

Surech de Mel

David McKenzie4

Christopher Woodruff

September 14, 2007 


\title{
Are Women More Credit Constrained? Experimental Evidence on Gender and Microenterprise Returns
}

\author{
Suresh de Mel, University of Peradeniya \\ David McKenzie, World Bank \\ Christopher Woodruff, UCSD
}

\begin{abstract}
This paper analyzes data from a randomized experiment on mean returns to capital in Sri Lankan micro-enterprises. The findings show greater returns among men than among women; indeed, returns were not different from zero for women. The authors explore different explanations for the lower returns among female owners, and find no evidence that the gender gap is explained by differences in ability, risk aversion, or entrepreneurial attitudes. Differential access to unpaid family labor and social constraints limiting sales to local areas are not important. However, there is evidence that women invested grants differently from men. A smaller share of the smaller grants remained in the femaleowned enterprises, and men were more likely to spend the grant on working capital and women on equipment. The gender gap is largest when male-dominated sectors are compared with female-dominated sectors, although female returns are lower than male returns even for females working in the same industries as men. The authors examine the heterogeneity of returns to determine whether any group of businesses owned by women benefit from easing capital constraints. The results suggest there is a large group of highreturn male owners and a smaller group of poor, high-ability, female owners who might benefit from more access to capital.
\end{abstract}

JEL codes: O12, O16, C93.

Keywords: Microenterprises; Gender; Microfinance; Randomized Experiment.

\footnotetext{
\# We thank Alejandrina Salcedo-Cisneros, Michael Callen, Susantha Kumara, and Jayantha Wickramasiri for excellent research assistance, and participants at several seminars for helpful comments. AC Nielsen Lanka administered the surveys on which the data are based. Financial support from NSF grants numbers SES-0523167 and SES-0617424 is gratefully acknowledged, along with additional support from the World Bank's Gender Action Plan.
} 


\section{Introduction}

Many microfinance organizations lend predominately or almost exclusively to women. For example, 97 percent of Grameen Bank's seven million borrowers are women $^{1}$, as are 70 percent of FINCAs borrowers ${ }^{2}$, and 65 percent of ACCIÓN's five million clients. ${ }^{3}$ Many of the justifications are economic in nature. Women are argued to be poorer than men on average (e.g Burjorjee et al., 2002; FINCA, 2007), have less collateral, and hence be more credit-constrained (e.g. Khandker, 1998; SEAGA, 2002). Muhammad Yunus (2004, p. 4078) writes that "women have greater long-term vision and are ready to bring changes in their life step by step. They are also excellent managers of scarce resources, stretching the use of every resource to the maximum".

But are women in low-income countries more constrained by finance than men? There is surprisingly little evidence on this question. Udry (1996) and others provide some evidence that men are favored in intra-household allocation of resources in rural households. Studies of microfinance clients in several countries suggest that femaleowned enterprises grow more slowly and generate lower profits than male-owned enterprises. ${ }^{4}$ But the samples for studies of clients of microfinance programs reflect selection decisions both on the part of enterprise owners as to whether or not to apply for a loan, and on the part of lenders as to whether or not to lend. The limited work on returns to capital in the broader population of microenterprises seldom differentiates returns by gender, and is still subject to the problem that capital stock is not exogenously determined. We are unaware of any convincing evidence on gender differences in the productivity of incremental investments across households. We provide evidence on that in this paper, using data from a field experiment among microenterprises in Sri Lanka.

For the experiment, we sampled microenterprises with less than US\$1000 in equipment and working capital in three districts in southern Sri Lanka. We provided random grants, half in cash and half as purchases of inputs or equipment selected by the

\footnotetext{
${ }^{1}$ http://www.grameen-info.org/bank/index.html [Numbers as of May 2007], accessed August 15, 2007.

2 http://www.villagebanking.org/site/c.erKPI2PCIoE/b.2604299/k.FFD9/What is Microfinance What is Village Banking.htm, accessed August 15, 2007.

${ }^{3}$ http://www.accion.org/about key stats.asp [all clients 1976-2006], accessed August 15, 2007.

${ }^{4}$ Kevane and Wydick (2001) provide a survey of several studies of investment behavior of microenterprise owners by gender, with mixed results found. In their own work, they find no significant difference between male and female borrowers in Guatemala in their ability to generate increases in sales. See McPherson (1996), Mead and Liedhom (1998), and Grasmuck and Espinal (2000) for additional evidence on the size and growth of enterprises owned by men and women.
} 
enterprise owner, to about 60 percent of the sampled enterprises. Two-thirds of the grants were $\$ 100$ and the other third were for $\$ 200$, representing about 50 and 100 percent of the median capital stock. Randomization generates exogenous differences in the capital stock of firms, allowing estimation of the return to capital that is not subject to endogeneity concerns. In de Mel, McKenzie and Woodruff (2008a), we show that the mean real return to capital is around 5.3 percent per month, much higher than market interest rates. We also show that returns to capital are heterogeneous, varying with measures of ability, household liquidity, and the gender of the owner. With respect to gender, we find returns of around 9 percent per month in enterprises owned by males, but not different from zero in enterprises owned by females. Thus, not only does the average female owner have a lower return than the average male owner, but on average femaleowned enterprises see no return from grants which averaged 50 to 100 percent of the preexperiment capital stock.

In this paper, we explore various explanations for the large gender gap in returns, drawing on the existing literature in economics, sociology and anthropology. Aside from differential credit constraints, the literature suggests several reasons returns may differ for women and men. First, men have been found to re-invest a larger share of the profits generated into the business (Grasmuck and Espinal, 2000), perhaps reflecting the difference between men and women in spending priorities. Men may also have more power within the household, giving them more access to unpaid labor of older children or to resources generated by their spouse (Ypeij 2000). Either social conventions or the need to be near home to watch children may lead women to work in different industries than men. The same factors may limit the ability of women to travel, reducing the size of their sales market, and hence demand for their goods. Because women are not continually in the labor market, they may have more limited business networks (Ypeij 2000). Finally, women may differ with respect to risk aversion or ability.

We put structure to these alternative explanations with a simple model of investment. The model shows that returns could vary due to differences in access to credit, differences in access to capital and labor within the household, differences in the markets for output, differences in entrepreneurial ability, differences in risk aversion, and differences in the sector of work. We find that the gender difference in returns to the 
treatments remains after controlling for various measures of access to credit, wealth, risk aversion, and a rich set of ability measures. The data suggest that women do invest their grants differently than men. Over the three years our surveys span, we find that on average none of the $\$ 100$ grants remain in female-owned enterprises, while all of the smaller grants remain in male-owned enterprises. Females, on the other hand, invest and retain in the business a somewhat larger portion of the \$200 grants. Compared with men, women were more likely to invest in equipment like ovens, sewing machines, or furniture, and less likely to invest in inventories and working capital.

But we find a marked difference between males and females in the returns generated by grants which are invested. As with the returns to the treatments, these differences are not explained by differences in measured ability, differences in entrepreneurial attitudes, the location of the business, or the percentage of sales made outside of the immediate neighborhood. Differences in sector of work may explain some of the difference. The gap in returns is much larger when we compare female-only industries such as lace to male-only industries such as repair services. Nevertheless, we still find women to have returns near zero in industries in which both male- and femaleowned enterprises both comprise at least 25 percent of the sector's firms.

As with any finding based on data from a single country, we should ask whether the findings are likely to hold in other regions or countries. Using cross sectional data from Brazil and Mexico, we show that similar gender differences appear in urban households in these countries. Women earn a significantly lower return on marginal investments of capital, and the gap is larger in sectors in which either males or females predominate and smaller in sectors in which both males and females are active.

Finally, while the results from the Sri Lankan data show zero average return for women, they do not imply that there are no female-owned enterprises which have high returns. In the final section of the paper we examine the heterogeneity of returns among female-owned enterprises, and show that returns are indeed high for the subset of highability, financially-constrained firms. However, at least in our data, male-owned firms are on average more constrained and have higher returns to marginal capital investments, suggesting an economic efficiency argument for directing more resources towards them. 
The remainder of the paper is structured as follows. Section 2 describes the experiment and Sri Lankan context. Section 3 estimates the mean treatment effect and return to capital by gender. Section 4 provides a simple model to detail avenues through which returns may differ by gender, and Section 5 explores these empirically. Section 6 explores non-experimental data from Brazil and Mexico to see if the pattern of returns is similar in those countries, Section 7 investigates the heterogeneity of returns across female-owned enterprises, and Section 8 concludes.

\section{Data and Experimental Design}

We summarize here the sample of microenterprises and the experiment which randomly provided grants to some microenterprise owners. More details on the basic experimental design can be found in de Mel, McKenzie and Woodruff (2008a).

\subsection{Participants and Survey design}

The goal of our experiment was to provide a positive shock (in the form of a grant) to the capital stock of firms, and measure the return to this shock. Our target population was low-capital microenterprise owners, those with less than 100,000 Sri Lankan rupees (LKR, about US\$1000) in capital, excluding land and buildings. The upper threshold assured that the grants our budget allowed us to provide would result in measurable changes in capital stock. Additionally, previous research had suggested that returns to capital were particularly high for enterprises with very low capital stocks (McKenzie and Woodruff, 2006). In addition to the capital stock threshold, a microenterprise owner had to fulfill all of the following conditions to be included in our sample:

(a) be self-employed full-time (at least 30 hours per week) outside of agriculture, transportation, fishing and professional services;

(b) be aged between 20 and 65; and,

(c) have no paid employees.

Using the 2001 Sri Lankan Census, we selected 25 Grama Niladhari divisions (GNs) in three Southern and South-Western districts of Sri Lanka: Kalutara, Galle and Matara. A $\mathrm{GN}$ is an administrative unit containing on average around 400 households. We used the Census to select GNs with a high percentage of own-account workers and modest 
education levels, since these were most likely to yield enterprises with invested capital below the threshold we had set. GNs were also stratified according to the degree of exposure of firms to the December 26, 2004 Indian Ocean tsunami. A door-to-door screening survey of 3361 households in these GNs was then conducted to identify firms whose owners satisfied the criteria listed above. In April 2005, the first wave of the Sri Lanka Microenterprise Survey (SLMS) surveyed the 659 firm owners which the screen identified as meeting these criteria. After reviewing the baseline data, 42 firms were dropped because they exceeded the capital stock threshold, or because a follow-up visit could not verify the existence of the enterprise. This gives a baseline sample of 617 microenterprises. The implications of the sample design for the selectivity of the sample of female and male owned enterprises is discussed in more detail in Appendix A.

In this paper we exclude the firms which suffered damage to business assets as a result of the tsunami, since recovery of assets damaged by the tsunami might affect returns to capital. This leaves 405 firms to be used in this paper, of which 197 are run by males and 190 by females. For the remaining 18 firms both husband and wife claim themselves as owner. Given their small number, we also drop these dual owner firms. The result is a sample of 387 firms almost evenly split by gender and across two broad industry categories: retail sales, and manufacturing/services. Firms in retail trade are typically small grocery stores. The manufacturing/services firms cover a range of common occupations of microenterprises in Sri Lanka, including sewing clothing, making lace products, making bamboo products, repairing bicycles, and making food products such as hoppers and string hoppers.

The SLMS then re-interviewed the owners of these firms at quarterly intervals for two years, and semi-annually for a third year. We use 11 waves of data, with the eleventh wave gathered in April 2008. In each wave, firm owners were asked about profits, revenues and expenses, changes in physical capital stock, and levels of inventories on hand. Profits were obtained through direct elicitation, which we find to be more reliable than constructing profits from detailed questions on revenue and expenses (de Mel, McKenzie and Woodruff, 2008b). Nominal profits were converted into real profits using 
the monthly Sri Lanka Consumers' Price Index. ${ }^{5}$ Each round also attempted to collect additional information about the firm or owner, in the form of special modules to measure owner ability, risk aversion, labor history, and other characteristics. We will discuss some of these measures in detail later in the paper. In addition, the first, fifth, and ninth and eleventh waves of the panel also included a household survey, measuring household expenditure, school attendance, and work participation of all household members.

Attrition in the SLMS is quite low. 370 of our 387 firms reported profits in the baseline survey. In the fifth wave (one year later), 348 firms reported profits, an attrition rate of only 5.9 percent. In the eleventh wave (three years after the baseline), we still have 319 firms with reported profits, for cumulative attrition of 13.8 percent. We concentrate our analysis on the unbalanced panel of 365 firms reporting at least three waves of profit data. There is no significant difference in attrition rates by gender: 63.5 percent of males are in all 11 waves, compared to 63.7 percent of females, 93.4 percent of males have at least 3 waves and are included in the sample we used after trimming large changes in profits, compared to 95.8 percent of females ( $p$-value $=0.22$ ).

\subsection{The Experiment}

Firms were told before the initial survey that as compensation for participating in the survey, we would conduct a random prize drawing, with prizes of cash or inputs/equipment for the business. The prize consisted of one of four grants: 10,000 LKR $(\sim \$ 100)$ in materials for their business, 20,000 LKR in materials, 10,000 LKR in cash, or $20,000 \mathrm{LKR}$ in cash. In the case of in-kind grants, the materials were selected by the enterprise owner, and purchased by research assistants working for the project. ${ }^{6}$ Cash

\footnotetext{
5 Source: Sri Lanka Department of Census and Statistics, http:/www.statistics.gov.lk/price/slcpi/slcpi monthly.htm [accessed February 17, 2007]. Inflation was low over the first year of the survey, with a 4.0 percent annual rate. Inflation was higher in the second and third years of the survey, with an annual rates of 18.6 percent between March 2006 and March 2007, and 28.0 between March 2007 and March 2008. The Sri Lankan price indices were revamped in November 2007, and the all island index we use was discontinued. We estimate the March 2008 value of the index by applying the rate of increase in the Colombo area index between March 2007 and March 2008.

${ }^{6}$ In order to purchase the goods for these entrepreneurs receiving in kind treatments, research assistants visited several firms in the evening to inform them they had won an in kind prize. The winning entrepreneurs were asked what they wanted to buy with the money, and where they would purchase it. The research assistants then arranged to meet them at the market where the goods were to be purchased at a
} 
treatments were given without restrictions. Those receiving cash were told that they could purchase anything they wanted, whether for their business or for other purposes.

After the first round of the survey, 124 firms were randomly selected to receive a treatment, with 84 receiving a 10,000 LKR treatment and 40 receiving a 20,000 LKR treatment. The randomization was done within district (Kalutara, Galle, and Matara) and zone (unaffected and indirectly affected by the tsunami). A second lottery was held after the third round of the survey, with an additional 104 firms selected at random from among those who didn't receive treatment after the first round: 62 receiving the 10,000 LKR treatment and 42 the 20,000 LKR treatment. In each case half of the firms received the treatment in cash, and the other half in kind. Allocation to treatment was done $e x$ ante, and as a result, there were an additional seven firms who were assigned to receive treatment after round 3, but who had attrited from the survey by then. Finally, a token cash payment of 2,500 LKR $(\sim 25)$ was made after round 5 to firms which had not already received a treatment. This payment was not discussed in advance with firms, and was presented as a thank-you for their continued participation in the survey. ${ }^{7}$

The median initial level of invested capital, excluding land and buildings, was about 18,000 LKR, implying the small and large treatments correspond to approximately 55 percent and 110 percent of the median initial invested capital. The 10,000 LKR treatment was equivalent to about three months of median profits reported by the firms in the sample, and the larger treatment equivalent to six months of median profits. By either measure, the treatment amounts were large relative to the size of the firms.

In de Mel, McKenzie and Woodruff (2008a) we show that we can not reject equality of effects of the cash and in kind treatments, nor can we reject linearity of the treatment effect with the 20,000 LKR treatment having double the effect of the 10,000 LKR treatment. For most of the analysis, then, we pool the cash and in-kind treatments, to create a single treatment variable which varies in amount. We will test whether pooling

\footnotetext{
specified time the next day. Thus, the goods purchased and the place/market where they were purchased were chosen by the entrepreneurs with no input from the research assistants.

${ }^{7}$ The initial funding covered five waves of the survey. The 2,500 rupee payment was made to limit attrition after additional funding was obtained to extend the survey for an additional four waves. We count the 2,500 LKR payment as a treatment in the analysis because owners told us they invested a similar amount of each of the three cash amounts in the enterprise, but the results are not affected if this payment is instead ignored.
} 
the 11 rounds of the data is reasonable, or whether the impact of the treatment changes with the time since treatment.

\subsection{Verifying Randomization}

Note that allocation to treatment was not stratified by gender. Nevertheless, provided the sample sizes are large enough, randomization will still lead the treated women to be comparable in terms of pre-treatment characteristics to the untreated women, and similarly for men. We verify this for observable characteristics in Table 1. Randomization does appear to have given comparable treatment and control groups in terms of baseline observable variables. For both men and women we see no significant difference in baseline profits, sales, capital stock, and owner characteristics between firms which are later treated and firms which are in the control group.

\section{Mean Treatment Effects and Returns to Capital by Gender}

To test whether the treatment has the same mean impact on business profits for female owners as it does for male owners we estimate for firm $i$ in period $t$ :

$$
\begin{aligned}
\text { PROFITS }_{i, t} & =\alpha+\beta \text { AMOUNT }_{i, t}+\gamma \text { AMOUNT }_{i, t} * \text { FEMALE }_{i} \\
& +\sum_{s=2}^{9} \theta_{s} \delta_{s}+\sum_{s=2}^{9} \kappa_{s} \delta_{s} * \text { FEMALE }_{i}+\lambda_{i}+\varepsilon_{i, t}
\end{aligned}
$$

Where $A M O U N T_{i, t}$ is an indicator of how much treatment firm $i$ had received at time $t$, coded in terms of $100 \mathrm{LKR}$ so that the coefficients can be read as monthly percentage returns. AMOUNT therefore takes value 100 if by time $t$ the firm had received the 10,000 LKR treatment, 200 if the firm received had the 20,000 LKR treatment, 25 if they had received the 2,500 LKR payment after round 5, and 0 if they were untreated as of time $t$. We include individual fixed effects to account for any time-invariant characteristics of owners that also influence profits. Since randomization appears to have held on the subsamples, including these effects is not necessary, but their inclusion can improve efficiency by accounting for more of the variation across owners in profits. The $\delta_{\mathrm{s}}$ are period effects, which we also interact with the female dummy variable to allow for different time paths of profits for male and female enterprises. The coefficient $\beta$ gives the 
mean treatment effect for males, and $\gamma$ provides the differential treatment effect for females. We test

i) $\quad \gamma \neq 0$ (female-owned businesses have a different increase in profits than male owned businesses from the treatment), and

ii) $\gamma+\beta=0$ (there is no effect of the treatment on profits of female-owned businesses).

Equation (1) shows the impact on business profits of giving cash or materials to firm owners. Since some of the grant may not be invested in the business (even the in-kind grant may be partially de-capitalized), this will not give the return to capital. Moreover, if male and female owners invest different amounts of the treatment in their business, we may find different treatment effects despite similar returns to capital. We therefore also estimate the returns to capital directly by using the treatment amount to instrument capital stock $K_{i, t}$ in the following regression:

$$
\begin{aligned}
\text { PROFITS }_{i, t} & =\alpha_{1}+\beta_{1} K_{i, t}+\gamma_{1} K_{i, t} * \text { FEMALE }_{i} \\
& +\sum_{s=2}^{9} \theta_{1 s} \delta_{s}+\sum_{s=2}^{9} \kappa_{1 s} \delta_{s} * \text { FEMALE }_{i}+\lambda_{1 i}+v_{i, t}
\end{aligned}
$$

Capital stock is measured as the total value of capital stock and inventories, excluding land and buildings. We can then test whether the returns to capital differ by gender $\left(\gamma_{1} \neq 0\right)$ and whether the returns to capital are zero for female enterprises $\left(\gamma_{1}+\beta_{1}=0\right)$.

\subsection{Gender Differences in Treatment Effects and Returns}

We begin by using real profits as the dependent variable. However, since profits include the earnings of the firm owner, any increase in profit from the treatment will be a combination of the return to capital and of the return to the owner of any adjustment in labor hours worked. Recall that since we are including individual fixed effects, the average hours of work are already implicitly adjusted for, and it is only changes in hours that we need worry about. When we estimate equation (1) using own hours worked as the dependent variable, we find the mean treatment effect is an increase of 1.8 hours per 
week for males, and a 0.3 hours per week for females. We can not reject that the change in hours is the same for males and females, and neither effect is significant. ${ }^{8}$

To isolate the impact of capital, we subtract the implicit wage earned by the firm owner. We estimate the marginal return to own labor using the baseline data to regress profits on capital stock, owner characteristics, and hours of work. We allow the hours effect to vary by three education levels and by gender. The value of an additional hour worked varies from zero to 9.2 rupees per hour.

Profit data are noisy. Measurement error can cause extreme changes in profits from one period to the next, reducing our power to detect changes in profits resulting from the treatments. We verified with the survey firm all observations with very large changes in either direction from one period to the next. Many of these were keypunch errors, which we corrected. Others may be errors of enumerators made in the field, but we have no way to verify this. For several observations with a large fall in profits, the survey firm told us that the business was closed for a period because of illness of the owner, or because of a lack of demand. Because these occurrences represent real risks of operating a business, we choose to trim only the top $1 \%$ of the sample ranked by changes in profits (in both percentages and levels). In practice, this trims observations for which profits increase by more than 608 percent or 15,000 LKR from one quarter to the next. ${ }^{9}$

Table 2 reports the results of estimating equations (1) and (2). Columns 1 and 2 show the mean treatment effect for real profits and real profits adjusted for hours worked by the owner. Columns 3 through 4 display the corresponding returns to capital regressions. Column 1 shows that a 10,000 LKR treatment increases real profits for treated males by 804 LKR per month, or 8.0 percent of the treatment amount. However, there is a large negative and significant gender interaction. The overall female effect is the sum of the female interaction and overall effect, and is -20 rupees or negative 0.20 percent per month, which is not statistically significant from zero. That is, we can not

\footnotetext{
${ }^{8}$ There is a significant increase in hours worked in the periods immediately following treatment, but this dissipates with time. In the period immediately following treatment, hours worked increases by 4.4 hours per week for males and 4.6 hours per week for females, both significant at the .05 level. In the second or later rounds after treatment, however, the measured effect on male hours returns very close to zero while the effect on female hours worked is always negative but insignificant.

${ }^{9}$ Note that if the increase represents a permanent change in the operation of the business, then we will lose only one observation, since in subsequent quarters growth rates will be modest again. The observationspecific trimming thus eliminate coding errors without excluding firms which are growing rapidly.
} 
reject that the treatment has no effect on mean profits for female-owned enterprises. Column 2 shows that the gender gap is not caused by differential adjustments in labor supply after the treatment. If anything, since men increase hours worked slightly more than women after treatment, controlling for hours worked increases the gender gap (column 2). By either measure, we find large positive and significant treatment effects for males, whereas treatment effects for women are not statistically different from zero, with negative point estimates.

In columns 3 and 4 we examine gender differences in returns to capital. Column 3 uses real profits as the dependent variable, ignoring the effect of the capital injection coming through hours worked, while column 4 adjusts profits for the value of the owner's time. In either case, the mean real returns to capital are estimated to be just over 11 percent per month for males, and slightly negative but not significantly different from zero for females. Note that the first-stage estimating the effect of treatment on capital stock levels shows a coefficient on the treatment amount of 0.73 for males and 0.70 for females, suggesting that on average 73 percent of the treatment given male owners ended up as capital stock for the business, while females invested almost as much. We explore this in more detail below.

The final two columns of Table 2 allow the treatment effect to vary with the number of quarters since the treatment was administered. If the initial shocks generate large profits, we might expect some part of those profits to be reinvested in the enterprise. On the other hand, shocks to household cash needs might lead to some disinvestment of the treatments over time. We find no significant trend for either males (Column 5) or females (Column 6). For both males and females, the standard errors increase with time after treatment, suggesting an increasing dispersion over time. Finding no significant time trend, we pool the data across all 11 rounds of the survey for the remainder of the paper.

\subsection{Investment of Treatments}

The first stage results shown on the bottom panel of Table 2 indicate that females retained an average over the eleven survey rounds of 70 percent of the treatment amount in the enterprise. The comparable percentage for males is slightly higher, 73 percent. We examine the investment decisions more closely in Table 3. Note that once we divide the 
sample by gender and treatment level, the sample sizes are modest. These results should therefore be viewed as suggestive rather than definitive. Table 3 shows that the investment behavior differed by treatment level. The right hand side variables are all binary variables indicating the gender and treatment levels. The first row of column 1 indicates that averaged over the eleven survey rounds, males invested 138 percent of the smaller treatment in their enterprises. This suggests the use of complementary resources or the reinvestment of generated profits by male owners. Females, on the other hand, invested none of the 10,000 LKR treatments. The female interaction term is -1.39 , meaning that the measured investment level is -0.01 for females. But for the larger treatment amounts, females invested, if anything, more than males. While males invested just over 60 percent of the 20,000 LKR treatment, females invested 85 percent of the larger treatment (1.22 plus 0.48 divided by two to reflect the treatment amount). The second column of Table 3 limits the sample to the single quarter immediately following the treatment, in order to show the immediate investment effects. Females do appear to invest some part of the 10,000 LKR treatment, though only 22 percent of this treatment finds its way into the enterprise in the quarter immediately following the grant. Males had invested just over 60 percent of the smaller treatment within the first three months. ${ }^{10}$

Given these differences in the response of investment, column 3 of Table 3 shows a regression which allows the returns to the treatment to vary by treatment level and gender. The pattern of returns generally reflects the pattern of investment. Males receiving the 10,000 LKR treatment have profit increases which are greater than those of males who received the larger treatment. This is consistent with the fact that males invested on average 138 percent of the smaller treatment and only 63 percent of the larger treatment. We do not find any increase in profits for females following the smaller treatment, consistent with the fact that no part of that treatment found its way into the enterprise. However, even females receiving the larger treatment did not obtain higher profits, in spite of the fact that they invested 85 percent of the treatment amount.

\footnotetext{
${ }^{10}$ Owners receiving cash grants were asked in the survey following the treatment how they had spent the cash grant. Among those receiving the 10,000 LKR grants, females report spending significantly less on the business $(4,900$ vs. $7,700, \mathrm{p}<.01)$ and more on household durable or nondurable consumption $(2,700$ vs., $1,600, \mathrm{p}=.09)$.
} 
In addition to investing different percentages of the grants, did males and females invest in different types of assets? For the half of the treatments given in kind, we have very detailed information on the purchases. For the half given as cash, we know from follow-up surveys whether the initial investments were made in inputs or equipment. Males invested a larger share of their grants in inventories and working capital (58 percent vs. 45 percent for female, $\mathrm{p}=.03$ ). Among the equipment purchases, women appear to have spent more on items which have uses both in the business and in the home - sewing machines, ovens, cookers, furniture, and the like. This largely reflects the fact that they are more likely to work in food processing and garments. But our profit data will not reflect the consumption value to the household of the purchases. For both males and females, we find weak evidence that the return to investments in equipment is lower than the return to investments in working capital, with the gap slightly larger for females. Columns 4 and 5 of Table 3 show the increase in profits as a function of the amount spent on working capital and the amount spend on capital equipment. For males, working capital investments have returns of 8.5 percent per month, while equipment investments return 5.3 percent per month. For females, the comparable estimates are 1.4 percent for working capital and -5.8 percent for equipment. The somewhat larger gap for females may reflect the greater value in home consumption of the equipment purchased by females.

In sum, we find that females invest little of the smaller treatment amount, but more of the larger treatment amount than do males. Females who do invest the grants in the enterprise show no increase in profits as a result. We next develop a simple framework for thinking about investment decisions in household enterprises.

\section{A Simple Model to Explain Why Returns May Vary by Gender}

With perfect markets and diminishing returns to capital, we would predict that in steady state all firms will chose their capital stock such that the marginal return to capital equals the market interest rate. In practice, however, both credit and insurance markets are imperfect, which can lead marginal returns to vary across firms and owners. A simple model can be used to identify the main potential sources of heterogeneity in returns, which can then be used to investigate gender differences in returns. 
We modify the model in de Mel, McKenzie and Woodruff (2008a) to allow for differences in the production function by industry. Consider a simple one-period model in which an enterprise owner supplies labor inelastically to the business. The enterprise owner is endowed with entrepreneurial ability $\theta$ and has chosen to work in sector $s$. Males and females of the same entrepreneurial ability may have chosen different sectors to work in due to differences in preferences, or to societal norms. The owner can finance capital stock $K$ through the formal credit market by borrowing $(B)$, or through its internal household capital market, by allocating $A_{K}$ of its endowment of household assets $(A)$ or $I_{K}$ of wage income $n w$ earned by the $n$ other working age adults.

The microenterprise owner's problem is then to choose the amount of capital stock, $K$, to invest in the business, subject to its budget and borrowing constraints:

$$
\text { Max EU(c) }
$$

$\left\{\mathrm{K}, \mathrm{B}, \mathrm{A}_{\mathrm{k}}, \mathrm{I}_{\mathrm{k}}\right\}$

Subject to:

$$
\begin{aligned}
& c=\varepsilon f_{s}(K, \theta)-r K+r\left(A-A_{K}\right)+\left(n w-I_{K}\right) \\
& K \leq A_{K}+I_{K}+B \\
& B \leq \bar{B} \\
& A_{K} \leq A \\
& I_{K} \leq n w
\end{aligned}
$$

Where $\varepsilon$ is a random variable with positive support and mean one, reflecting the fact that production is risky, and $r$ is the market interest rate. The production function of the firm, $\mathrm{f}_{\mathrm{s}}(\mathrm{K}, \theta)$ depends on the sector s, level of capital stock, and on $\theta$, the ability of the entrepreneur.

With incomplete markets, the solution to the owner's first-order condition for $K$ is:

$$
f_{s}^{\prime}(K, \theta)=\frac{1}{1+\frac{\operatorname{Cov}\left(U^{\prime}(c), \varepsilon\right)}{E U^{\prime}(c)}}\left[r+\frac{\lambda}{E U^{\prime}(c)}\right]
$$

where $\lambda$ is the lagrange-multiplier on condition (4), and is a measure of how tightly overall credit constraints bind. This in turn will depend on both the supply of capital available from both the external and internal sources, and on the demand for credit, which in turn depends on the production function and own ability. 
Equation (8) therefore suggests that gender differences in returns to capital may arise from the following factors, which we will next investigate empirically:

(a) Differences in access to capital from the external market: Ceteris paribus, returns should be higher for owners with less access to external credit. One reason given for focusing microfinance on women is that they typically have more difficulty accessing financial services. ${ }^{11}$ If so, then women should have higher returns.

(b) Differences in the shadow cost of capital within the household: Ceteris paribus, returns should be higher for owners from poorer households, who are less able to finance business investments from own savings. Advocates of focusing microfinance on women also claim that women are more likely to be poor ${ }^{12}$, in which case they should have higher returns. However, another reason for microfinance's focus on women is the belief that women are more likely than men to spend the proceeds on improving family welfare, and investing in children's health and education. ${ }^{13}$ This may also lead to a high shadow cost of capital within the household, causing women to devote less of the treatment to their business. This could potentially explain why there is less of a mean treatment effect for women than men. Nevertheless, the higher shadow cost of capital for women should also mean higher returns on the capital that is invested.

(c) Differences in entrepreneurial ability: If ability and capital stock are complements in production, then, conditional on a given set of internal and external resources, individuals with higher entrepreneurial ability will be more constrained and thus have higher returns. If women entrepreneurs have less business ability, this could potentially explain the lower returns.

(d) Differences in the sector of production: An individual will be more constrained, and thus have higher returns, if their industry has a greater efficient scale. If women select into industries with less scope for growth, then even with the same access to credit and entrepreneurial ability as men, they will have lower returns.

\footnotetext{
${ }^{11}$ See e.g. Niethammer et al. (2007); SEAGA (2002)

12 See e.g. Niethammer et al. (2007); Burjorjee et al. (2002); FINCA (2007).

${ }^{13}$ See e.g. Yunus (2004), Burjorjee et al. (2002).
} 
(e) Differences in risk: Finally, if insurance markets are missing, risk-averse individuals will underinvest, and hence have higher returns. Differences in risk aversion by gender could thus lead to differences in returns.

\section{Empirically Investigating Why Returns Are So Low for Women}

The model in the last section suggests several possible explanations for the gender differences we observe in returns. We test each of these in turn.

\subsection{Do Women Invest More of the Treatment on Children?}

A high shadow cost of capital within the household, whether driven by a desire to spend money on children's education and health, or due to husbands capturing the treatments made to females could lead to less of the treatments staying in female-owned businesses. We showed in Table 3 that females appear to have invested less of the smaller treatment amount, but no less of the larger. In Table 4, we use the survey data to test whether the treatment has a greater effect on schooling, expenditures and household asset accumulation in households of female microenterprise owners than in households of male microenterprise owners. Columns 1 to 3 of Table 4 use the household surveys taken to estimate the impact of the treatment on school attendance of 5 to 12 year olds, 12 to 15 year olds, and 17 to 18 year olds respectively. School attendance information was gathered only in the April waves of the survey and the sample for these regressions is limited to those households with children of the specified age. We find that the treatment has no effect on school attendance regardless of the gender of the owner.

We find similarly insignificant differences on expenditures for groceries, health and education between households of female owners and households of male owners. (See columns 4 through 6 of Table 4). We do find significant differences in the rate at which household durable goods ownership increases, and in financial assets. Column 7 of Table 4 takes as the dependent variable the first principal component of a vector of 17 household assets, including landline and cellular telephones, television, autos, bicycles and gold jewelry. The weights in the index are derived from baseline data. Asset ownership increases generally in the sample, but the regression results reported in column 7 shows that the increase is significantly larger in households of male enterprise owners 
who received who received the grants. As with enterprise profits, asset ownership in households of female entrepreneurs was unaffected by the treatments.

The April 2007 and April 2008 household modules contain questions about financial assets. Over the two rounds, more females say they have a current account, a fixed deposit account or a savings account with a bank or other financial institution (43 percent vs. 36 percent of males, $\mathrm{p}=0.04)$. Households of enterprise owners receiving treatments are slightly more likely to have at least one such account (42 percent vs. 36 percent, $\mathrm{p}=0.12$ ). However, the treatment effect is again limited to households of male owners: 43 percent of both treated and untreated female enterprise owners report having an account, while 41 percent of treated males and only 29 percent of untreated males say they have an account. ${ }^{14}$

The schooling and current expenditure data reveal no significant treatment effects for either males or females. The lack of any impact of the treatment on health and education expenditures may be due to the fact that Sri Lanka has a good, inexpensive, state system of schooling and health care. Schooling is compulsive up to age 14, and over 91 percent of children in our sample of this age are actually attending school. In countries where education and health expenses are larger burdens on households, we might find more of the treatment being spent on these categories. But males show a large gain in both household durable and financial assets following treatment, while females show no gain in assets following treatment.

\subsection{The Power to Allocate Resources}

The ability of the owner to invest the grants in profitable activities may be affected by her/his power in household decision making. (See Ashraf, 2008 and Duflo, 2005 for a discussion of the effect of empowerment on household expenditures.) We test whether decision making power affects the returns using responses to questions about who makes decisions regarding household expenditures and business investments. We find no significant effects of decision making for either female or male owners. Column 1 of Table 5 reports the effect of including a control for the number of 4 household

\footnotetext{
${ }^{14}$ Owners were also asked for the balances in the accounts. The reported balances are highly skewed, but show a similar patter. Treated households have higher balances, but only among household with male owners.
} 
purchasing decisions-purchases of food, clothing, durable goods, and other routine household expenditures - the business owner has a say in. Column 2 indicates whether the spouse of the owner has a say in business decisions related to reinvestment of profits and purchase of equipment. Neither variable is significantly related to the size of the treatment effect, and their inclusion has almost no effect on the magnitude of the return to treatment for either females or males. ${ }^{15}$

Women may also be unable to realize potential profits from capital investments because they are not able to increase the labor input in the enterprise. They may have a harder time expanding their own labor hours because of household responsibilities related to the care of children or elderly parents. Men may also have first claim on available household labor supplied by children (Ypeij 2000). We explore both of these possibilities, and find no support for either. As we noted above, the hours worked by male owners does increase slightly more following treatment than the hours worked by female owners, but the difference is far from significant. Column 3 of Table 5 shows that the number of hours worked in the enterprise by family members other than the owner is not affect by the treatment for either males or females. There is a modest negative coefficient on the female interaction term, but the effect is not significant either statistically or economically. In the $4^{\text {th }}$ column, we exclude from the sample all households with children under age 12 at the time of the baseline survey, or with adults over the age of 65 . The measured effect of the treatment is still large and positive for males and close to zero for females after imposing this restriction, although the smaller sample size results in larger standard errors and statistical insignificance. Thus, we find no evidence that differences in household decision making explain the lower returns earned by females.

Another way in which household bargaining power may manifest itself is through the gap between actual and reported outcomes. Are female microenterprise owners more likely than men to under report business income? One indication of this comes from questions we asked about why and how much "firms like yours" over- or under-report

\footnotetext{
${ }^{15}$ These questions were asked in the November 2007 round of the survey, well after the treatments were given. However, we find no effect of the treatment on any of the decision making measures. This may be the result of the fact that all of the female owners were already working and earning income before the baseline survey.
} 
profits. Women and men say that "firms like theirs" under report profits by very nearly the same amount ( 7850 from females vs. 8067 for males, $\mathrm{p}=0.55$ ). We also have data on who was present at the interview for each round after the baseline survey. If unempowered women are deliberately under reporting gains following treatment, we should expect to find lower reported profits when the spouse is present at the time the interview is conducted. The last column of Table 5 does show some evidence that the presence of the spouse matters for the general level of reporting profits - males underreport profits by 433 rupees and females by 216 rupees when their spouse is present. As a percentage of average profits, this is approximately the same for both groups. More importantly, however, the effect is the same in treated and untreated households. When we interact the presence of the spouse with treatment, the interaction term is small and statistically insignificant.

\subsection{Differences in Access to Capital}

One of the main reasons for the traditional emphasis of microfinance on women is a belief that women have less access to formal finance than men. In the baseline survey, firms were asked whether they had ever had a loan from banks, the government, microfinance, and different government programs. Only 1.8 percent have had a loan from a private bank, and 2.1 percent from a microfinance organization. 9.4 percent have had a loan from the government, 4.2 percent from the Sanasa Development Bank (an umbrella organization of small credit unions), 6.5 percent from the government's Samurdhi program, and 0.5 percent from other government programs such as IDRP and REAP. Combined across all of these sources, we find no significant gender difference: 23.4 percent of females and 23.5 percent of males have ever had a loan from one of these formal sources (Table 6).

The characteristics of females who had ever received formal credit are similar in many respects to those of female microenterprise owners who had never received formal credit. In particular, they do not significantly differ in age, education, digit-span recall, household asset ownership, household size, or the number of wage workers in the household. It is thus not the case that credit is more likely to go to firm owners with characteristics that our model suggests would be associated with the highest returns. 
Most firm owners in our sample financed the start-up and ongoing capital investments through own savings and loans from family. Our survey contains two measures of the household internal capital market: the number of paid wage workers in the household, and an index of household durable assets constructed as the first principal component of baseline indicators of ownership of durable assets such as fans, radios, cameras, televisions and motorcycles. Table 6 shows that on average female owners have more wage workers and higher household assets to draw upon, measured in the baseline survey. As a result, we would expect females to be less constrained, and hence earn lower returns.

To investigate whether differences in access to capital can explain the gender difference in treatment effects, we examine the gender interaction term after controlling for interactions between measures of access to credit and the treatment amount. That is, we estimate the following equation, for a given set of $H$ potential explanators $\mathrm{X}_{\mathrm{s}}$,

$$
\begin{aligned}
\text { PROFITS }_{i, t} & =\alpha+\beta \text { AMOUNT }_{i, t}+\gamma \text { AMOUNT }_{i, t} * \text { FEMALE }_{i}+\sum_{h=1}^{H} \pi_{h} \text { AMOUNT }_{i, t} * X_{h, i} \\
& +\sum_{s=2}^{9} \theta_{s} \delta_{s}+\sum_{s=2}^{9} \kappa_{s} \delta_{s} * \text { FEMALE }_{i}+\sum_{h=1}^{H}\left(\sum_{s=2}^{9} \varphi_{h, s} \delta_{s} * X_{h, i}\right)+\lambda_{i}+\varepsilon_{i, t}
\end{aligned}
$$

We demean all the $\mathrm{X}$ 's, so that $\beta$ will give the mean treatment effect for males, and $\gamma$ the differential effect for females, evaluated at the mean of the other potential explanatory variables. We then examine how sensitive $\gamma$ is to the inclusion of these other variables, to determine whether the gender interaction is really reflecting gender differences in access to capital. We use profits adjusted for the value of the owner's labor input, as described above.

Table 7 shows the results. The first column repeats the basic result from Table 2. Columns 2 through 4 then show the impact of controlling for treatment interactions with access to bank loans, the number of wage workers, and household assets. Each of these controls shows a negative interaction effect, consistent with less constrained owners earning lower returns. However, controlling for these interactions does not lead to a significant change in the size of the negative female interaction term. We still find high returns for males, and can not reject the return being zero for females after these controls 
for differences in access to credit. Therefore it seems the supply side of the external and internal credit markets can not explain the difference in returns.

\subsection{Differences in Entrepreneurial Ability and Reasons for Going into Business}

The demand for credit will depend on the optimal size of the enterprise. If capital and ability are complements in production, more able owners will have higher optimal sizes. Hence, for a given supply of credit, more able owners will be further away from their optimal size and have higher marginal returns to capital.

Entrepreneurial ability is a multifaceted and nebulous concept, which is unlikely to be captured fully by general measures of ability such as years of education. The SLMS has an extremely rich set of measures of ability, allowing us to consider an array of possible measures for entrepreneurial ability. In Table 7 we show three such measures. Column 5 shows the standard measure, years of education. Column 6 shows Digit-span recall, a measure of short-term processing power, used in Djankov et al. (2005). Table 6 shows that females have significantly more education than males, but significantly less Digit-span recall. Table 7 finds that both these measures are significant in their interactions with the treatment amount, showing larger treatment effects to more able individuals. But again, the basic pattern of returns is unchanged by the inclusion of the ability measures. Males continue to show, on average, high returns and females near zero returns to the treatment.

Our survey also contains many measures developed by industrial psychologists to measure different facets of the entrepreneurial personality. Table 8 examines the robustness of the female interaction term to 19 alternative measures of owner ability and motivation. These include measures commonly found in economic studies, such as mother's and father's previous business experience; the time taken for individuals to solve a maze (median time was 53 seconds); entrepreneurial traits such as passion for work, tenacity (both from Baum and Locke, 2004); entrepreneurial self-efficacy; trust (taken from the General Social Survey); the achievement and power motivations of McClelland (1985); Work centrality (Mishra et al, 1990); Impulsiveness, from three questions on the Barratt Impulsiveness Scale; Financial Literacy (from Lusardi and Mitchell, 2006); internal locus of control (Rotter, 1966) and our own questions on 
reasons for going into business, on whether or not the business operates out of the home, and on whether or not their friends and family consider the owner an organized person. None of these characteristics are significant when interacted with the treatment effect, and the female interaction stays large, negative, and significant. We thus conclude that differences in entrepreneurial ability, however measured, do not explain the low returns to females.

\subsection{Differences in Risk Aversion}

We measure risk aversion as the implied coefficient of relative risk aversion obtained by playing lottery games for real money with the firm owners (see de Mel, McKenzie, and Woodruff 2008a for details). Although there is a common presumption that women are more risk averse than men in many countries, we find that Sri Lankan female microenterprise owners are more likely to take risky gambles in these lottery games than male owners (Table 6). Since theory would predict that returns are higher for more risk averse individuals if missing insurance markets cause them to underinvest, the results of these lottery games suggest that differences in risk aversion will not explain the low returns for females. Indeed, we see this in column 8 of Table 7, where controlling for the interaction with risk aversion does not change the female interaction. This result is also robust to an alternative measure of risk aversion. We also followed the German Socioeconomic Panel in asking firm owners about the overall willingness to take risks in life, on a 10 point scale. This variable has a coefficient of -0.28 (s.e. 0.88) when interacted with the treatment amount, and the female interaction with treatment amount is -8.84 (s.e. 4.26), which is not significantly different from the baseline model. Thus differences in risk aversion do not explain the low returns to females.

\subsection{Differences in Industry and Ability to Expand the Business}

The large differences in treatment effects by gender do not appear to be explained by differences in access to capital, differences in ability, differences in risk aversion or differences in other entrepreneurial attitudes. The remaining potential reason for differences in returns according to our theoretical model is that there are differences in production technologies across gender. 
We investigate whether differences in sector of work help account for gender differences in returns in Table 9. The first column repeats the treatment effect and return to capital regressions found in Table 2. The next column then estimates a version of equation (9), which interacts the treatment amount with eight different industry dummy variables (to cover nine industries: retail sales, food sales, clothing, sales of non-food, lace, repair services, manufacturing, personal services and other services). The regression also allows the wave effects to vary with industry. This therefore involves adding eight interactions with amount and 80 additional wave effects. The results then show whether, within industry, females on average have different effects of the treatment than males. We find that the results are robust to controlling for differences across industry, with the female interaction becoming slightly more negative, and remaining significant. The returns for males fall slightly in magnitude to 5.91 percent, but remain significance at the 0.10 level.

We take a different approach in the last two columns of Table 9, considering more detailed industry coding. We classify firms into 73 industry classifications. For example, the broader industry of food sales gets divided into finer classifications such as fish sales, cashew nut sales, and fruit sales. In column 3 of Table 9 we then re-estimate the treatment effects restricting analysis to the narrow industries that both male and female owners constitute at least 25 percent of the firm owners in our sample. We limit the sample to detailed industries in which there are at least four enterprises. In this reduced sample the gender interaction is insignificant but of nearly the same magnitude as in the full sample. The point estimates suggest that for this sub-sample, women have average returns of 0.9 percent, compared to 13.7 percent for men. Finally, in the last column of Table 9 we consider narrow industries in which only men or only women operate in our sample. The gender difference is much larger in this subgroup - while male owners in industries without females have returns to capital of 9.5 percent, female owners in industries without males have returns to capital of negative 8.5 percent. Femaledominated occupations therefore appear to have particularly poor returns to capital.

One plausible explanation for the difference in returns across sectors relates to the potential for expanding the customer base after investing additional capital. On average female owners report that 68 percent of their customers are within $1 \mathrm{~km}$ of their business, 
compared to 60 percent for male owners (p-value of 0.027 for testing equality). Moreover, 48 percent of female firms have all their customers within $1 \mathrm{~km}$, compared to only 30 percent of men (the difference is significant with $p<0.001$ ). However, the propensity to sell locally, measured at the time of the baseline survey, is not significantly associated with returns to the treatments for either males or females. Thus it appears unlikely that the main explanation for the gender difference in returns across sectors is due to the geographic limitation of the market.

A second potential sector-related explanation is that female-owned businesses are more likely to be operated out of the home, where owners may be carrying out other tasks such as caring for family members or doing housework at the same time as operating their business. 74 percent of female-owned businesses in our sample operate out of the home, compared to 52 percent of male-owned businesses. However, Table 8 shows no significant interaction between treatment amount and dummy variables for operating a business out of the home, or for going into business to care for family members. The female-interaction coefficient does not significantly change when we control for either explanation. Thus industry differences also appear unlikely to be due to some firms being operated out of the home.

\section{External Validity}

The experimental results in this paper clearly demonstrate a lower return to capital in female-owned enterprises in Sri Lanka than in male-owned enterprises, with the sector of work appearing to explain some of this gender difference. As with any empirical result based on data from a single country, a question which then arises is whether the results of the experiment apply to other settings. In this section we provide suggestive (nonexperimental) evidence that the pattern of returns by gender is not limited to Sri Lanka.

We use microenterprise data from detailed microenterprise surveys in Brazil and Mexico. The Brazilian data come from the Economia Informal Urbano survey of 2003 (see Fajnzylber et al. 2006) and Mexican data from pooling the 1992, 1994, 1996 and 1998 National Survey of Microenterprises (ENAMIN) surveys (see McKenzie and Woodruff, 2006). For each survey we restrict our analysis to firm owners aged 18 to 65 , working more than 30 hours per week, with less than \$US500 of capital stock, exclusive 
of land and buildings. ${ }^{16}$ We convert profits and capital stock into U.S. dollars, and run the following cross-sectional regression:

$$
\text { PROFITS }=\alpha+\beta \text { FEMALE }+\gamma \text { CAPITAL }+\delta C A P I T A L * \text { FEMALE }+\pi^{\prime} X+\varepsilon
$$

Where FEMALE is a dummy variable for females, CAPITAL is capital stock exclusive of land and buildings, and $X$ is a set of controls for education, age, and own hours worked. The parameter $\gamma$ provides an estimate of the marginal return to capital for male enterprises, and $\gamma+\delta$ the marginal return for female owned enterprises. We are most interested in the sign and relative magnitude of $\delta$, the interaction between capital stock and the female dummy variable. Of course one is concerned that capital stock may not be exogenous in this regression, and may be correlated with unobserved characteristics of the owner or firm which also increase profits - a reason for carrying out a randomized experiment in the first place. Nevertheless, our previous experience (de Mel et al. 2008, McKenzie and Woodruff 2006, 2008) suggests that these non-experimental regressions are informative about the high returns to capital in microenterprises, and at present, they offer the only source of information for seeing whether there is any evidence that the results of our experiment apply in other countries.

Table 10 reports the results of this regression. We begin by pooling together all industries. Column 1 shows a return to capital of 16.6 percent in Mexico for males. Returns for females are 7.6 percent lower than those for males, a difference significant at the .01 level. Column 4 shows a higher return of 40 percent for males in Brazil, with female returns significantly lower by 13.2 percent. Thus in both countries there is evidence that the return to capital is substantially lower in female-owned microenterprises than in male-owned microenterprises.

Next we examine whether the return varies with the gender mix of the industries being considered in Mexico and Brazil. In Columns 2 and 5 we consider industries which are dominated by one gender, measured by having over 75 percent of the firms in the sample in this industry being of the same gender. Columns 3 and 6 consider gender-

\footnotetext{
${ }^{16}$ This upper limit on capital stock restricts the capital stock to the range over which most firms in our Sri Lanka experiment operate.
} 
mixed industries, in which both the male and the female share of firms in the industry in the sample exceed 25 percent. Similar to our experimental results, we see much bigger gender differences in returns in industries which are predominately the domain of one gender than in the gender mixed industries. This is particularly the case in Brazil, where the gender interaction is -19 percent in the industries where either males or females predominate, and an insignificant and positive 1.7 percent in the mixed-gender industries. In Mexico the differences are not as stark, but the gender interaction is 12.3 percent when restricted to industries where one gender dominates, compared to 8.1 percent in the mixed gender industries. Thus these results suggest that the experimental differences in returns according to the gender mix of the industry are also likely to generalize to other settings.

\section{Which Women Benefit from the Treatment?}

The above results show that the mean treatment effect is zero for female-owned businesses. However, Table 7 also showed that the treatment effect does significantly vary with ability. We therefore explore the heterogeneity of treatment effects within the sub-sample of female-owned businesses. Table 11 re-estimates the specifications in Table 7 on the female-owned sub-sample. Column 1 of Table 11 shows the negative and insignificant mean treatment effect for females. Columns 2 and 3 show evidence of higher returns to higher ability owners. Once we include all the controls in column 4 , we see that digit-span recall and household assets are associated with higher returns.

We use these specifications to estimate the mean treatment effect by observed characteristics. The bottom of Table 11 reports the percentage of female-owned businesses with mean returns lying in different ranges. For example, column 3 shows a large positive and significant coefficient for digitspan recall. The standardized digitspan recall has mean zero and ranges from -2.67 to 5.32. 48 percent of female-owners have low enough digitspan recall that their mean treatment effect is estimated to lie below zero. In contrast, 10 percent have an estimated mean treatment effect between 0 and 200 rupees, 20 percent an estimated mean treatment effect between 200 and 500 rupees, and

22 percent an estimated mean treatment effect of 501 rupees or more. When we include multiple interactions in column 4 , we find 59 percent of firms have mean treatment 
effects less than zero, 14 percent have them in the 0 to 500 rupee range, and 27 percent have mean treatment effects in excess of 500. Thus there is a sizeable share of female firms with high mean treatment effects, even though the mean treatment effect for females as a whole is negative.

\section{Discussion and Conclusions}

The economic argument for microfinance's focus on female-owned businesses is that female owners are likely to be poorer and more credit constrained, and to use resources more efficiently. If this is the case, we would expect returns to capital to be higher in female-owned firms. This paper provides evidence against this view, finding mean returns to capital to be zero among female-owned micro-enterprises in Sri Lanka. In contrast, returns to capital for male-owned enterprises are in excess of 11 percent per month. These large returns show that, on average, male-owned enterprises are more likely to generate the return on investment necessary to repay micro-loans.

Since the experiment gave grants, rather than loans, we are unable to provide evidence on another of microfinance's claims - that women are more likely to repay (in part because they are less mobile and have less alternative options for financing). ${ }^{17}$ Our results do show that there is a subset of women who have high enough returns to cover the costs of loans, namely poor, high ability women. However, although microfinance penetration in Sri Lanka is among the highest in the World, in our sample it is not the case that it has succeeded in targeting these high-return women, let alone the much greater number of men who have high returns to capital.

There is by now quite a lot of evidence that intra household consumption is affected by which household member generates income. For example, Duflo and Udry (2004) use rainfall patterns and the fact that men and women in rural Cote D'Ivoire produce different crops to show that income generation by females has implications for household expenditure patterns, even when total household income remains the same. Our experiment gave equal amounts of cash or in-kind grants to male and female microenterprise owners. We find very clear evidence that males turned the grants into a sustained source of income by making profitable investments in their enterprises. During

${ }^{17}$ See Morduch (1999). 
the three years following the grants, these gains resulted in accumulation of household durable goods and financial assets in the households of the male grant recipients. In contrast, females, on average, did not generate a sustained source of income from the grant. They did not do so either because they did not invest the grant in their enterprise, or because they did not earn additional profits when the grant was invested. Why women lack profitable investment opportunities, and why they are more likely to enter sectors with lower returns are questions which we see as first order for future research.

\section{References}

Ashraf, Nava (2008), "Spousal Control and Intra-Household Decision Making: An Experimental Study in the Philippines," American Economic Review, forthcoming.

Baum, J. Robert and Edwin A. Locke (2004) "The Relationship of Entrepreneurial Traits, Skill, and Motivation to Subsequent Venture Growth", Journal of Applied Psychology 89(4): 587-98.

Bluedorn, Allen C., Thomas J. Kalliath, Michael J. Strube, and Gregg D. Martin (1999) "Polychronicity and the Inventory of Polychronic Values (IPV)", Journal of Management Psychology 14(3/4): 205-231.

Burjorjee, Deena M., Deshpande, Rani, and Weidemann, C. Jean (2002), "Supporting Women's Livelihoods Microfinance that Works for the Majority. A Guide to Best Practices", United Nations Capital Development Fund, Special Unit for Microfinance. http://www.uncdf.org/english/microfinance/pubs/thematic papers/gender/supporting/part 1.php

de Mel, Suresh, David McKenzie and Christopher Woodruff (2008a) "Returns to Capital in Microenterprises: Evidence from a Field Experiment", Quarterly Journal of Economics, forthcoming.

de Mel, Suresh, David McKenzie and Christopher Woodruff (2008b) "Measuring Microenterprise Profits: Don't ask how the sausage is made", Journal of Development Economics, forthcoming.

Department of Census and Statistics (DCS) (2007) Sri Lanka Labor Force Survey: Final Report- 2006. Department of Census and Statistics, Colombo, Sri Lanka.

Djankov, Simeon, Edward Miguel, Yingyi Qian, Gerard Roland and Ekaterina Zhuravskaya, 2005, "Who are Russia's Entrepreneurs?," Journal of the European Economic Association 3(2-3): 587-97.

Duflo, Esther (2005) “Gender Equality in Development,” working paper,. MIT 
Duflo, Esther and Christopher Udry (2004). "IntraHousehold Resource Allocation in Cote d'Ivoire: Social Norms, Separate Accounts and Consumption Choices," NBER Working Paper No. 10498

Fajnzylber, Pablo, William Maloney, and Gabriel Montes Rojas. 2006. "Does Formality Improve Micro-Firm Performance? Quasi-Experimental Evidence from the Brazilian SIMPLES program.” Mimeo. World Bank.

FINCA (2007), "Frequently Asked Questions", http://www.villagebanking.org/site/c.erKPI2PCIoE/b.2394157/k.8161/Frequently_Asked Questions.htm [accessed August 15, 2007].

Grasmuck, Sherri and Rosario Espinal (2000) "Market Success or Female Autonomy? Income, Ideology, and Empowerment among Microentrepreneurs in the Dominican Republic," Gender and Society 12(2): 231-55.

Kevane, Michael and Wydick, Bruce (2001), "Microenterprise Lending to Female Entrepreneurs: Sacrificing Economic growth for Poverty Alleviation?", World Development, Volume 29, Issue 7, July, p. 1225-1236.

Khandker, Shahidur R. (1998), "Using microcredit to advance women", World Bank Premnote (November) No8. http://www1.worldbank.org/prem/PREMNotes/premnote8.pdf [accessed August 15, 2007].

Lusardi, Anna-Maria and Olivia Mitchell (2006) "Financial Literacy and Planning: Implications for Retirement", PRC Working Paper Series No. 2006-1

McClelland, D.C. (1985) Human Motivation. Glenview, IL: Scott, Foreman.

McKenzie, David and Christopher Woodruff (2006) "Do entry costs provide an empirical basis for poverty traps? Evidence from Mexican microenterprises", Economic Development and Cultural Change 55(1): 3-42.

McKenzie, David and Christopher Woodruff (2008) "Experimental Evidence on Returns to Capital and Access to Finance in Mexico", World Bank Economic Review, forthcoming.

McPherson, Michael A. (1996) "Growth of Micro and Small Enterprises in Southern Africa," Journal of Development Economics, 48: 253-77

Mead, Donald C. and Carl Liedhom (1998) "The Dynamics of Micro and Small Enterprises in Developing Countries," World Development 26(1): 61-74.

Morduch, Jonathan (1999), "The Microfinance Promise", Journal of Economic Literature, 37(4): 1569-1614. 
Mishra, S., R. Ghosh, and R. Kanungo (1990) "Measurement of Family Involvement: A cross-national study of managers", Journal of Cross-cultural Psychology 21(2): 232-48.

Niethammer, Carmen, Tania Saeed, Shaheen Mohamed, and Yasser Charafi (2007), "Women Entrepreneurs and Access to Finance in Pakistan", World Bank.

Rotter, J.B. (1966). "Generalized expectancies of internal versus external control of reinforcements". Psychological monographs.

SEAGA, Socio-economic and Gender Analysis Programme (2002), "A guide to Gender sensitive microfinance", FAO.

http://www.fao.org/sd/seaga/downloads/En/Microfinanceen.pdf [accessed August 15, 2007].

Udry, Christopher (1996). "Gender, Agricultural Productio0n, and the Theory of the Household,” Journal of Political Economy, Vol 104(5), pp. 1010-1046.

Ypeij, Annelou (2000) Producing Against Poverty: Female and Male Microentrepreneurs in Lima, Peru, Amsterdam University Press.

Yunus, Muhammad (2004), "Grameen Bank, Microcredit and Millennium Development Goals", Economic and Political Weekly, Vol. 39, No. 36, p.4077-4080. 


\section{Appendix A: Sample selection issues}

We set out to obtain a sample of enterprises with less than 100,000 LKR in capital stock, excluding capital invested in land and buildings. The initial sample for the experiment was from a random selection of households in 25 Grama Niladharis in the Sri Lankan districts of Kalutara, Galle and Matara. Grama Niladharis, or GNs, are administrative units with an average of about 400 households. The 25 GNs selected had high rates of self employment and moderate or low levels of education. A screening survey was used to select households into the final sample. The screen asked whether there was anyone in the household between the ages of 22 and 65 who was self employed. Those working in professional services, fishing, transportation and agriculture were eliminated. Those owning a motorized vehicle or hiring paid employees were also eliminated. These restrictions were made because enterprises in these industries, or those with employees or motor vehicles, are likely to have more than 100,000 LKR in capital. Finally, near the beginning of the survey given to enterprise owners meeting these criteria, we ask the owner whether the market value of invested capital excluding land and buildings was less than 5,000 LKR, between 5,000 and 50,000 LKR, between 50,000 and 100,000 LKR, or greater than 100,000 LKR. Those reporting capital stocks in excess of 100,000 LKR were not interviewed.

Because returns to capital are expected to be correlated with entrepreneurial ability, we are particularly interested in whether and how the sample's selection on ability differs between females and males. This will be affected first by decisions to participate in the labor force. Not surprisingly, men are much more likely to be active in the labor market than women. According to the 2006 Sri Lankan labor force survey, the labor force participation rate of 30-39 year old urban males is 96.4 percent, compared to only 34.4 percent for the same age urban females (DCS, 2007). Furthermore, only 22.7 percent of female workers are self-employed, compared to 30.8 percent of male workers. Thus selfemployed individuals are only 7.8 percent of prime age females, compared to 29.7 percent of prime age males. While we expect that selection of females into the labor market is determined at least in part by ability, attitudes toward risk, and related factors. But if capital flows mainly to those with entrepreneurial experience, then those active in 
the labor market are arguably the relevant sample for analysis, so selection at this level is of less concern.

Conditioning on self employment, the sampling criteria may still result in different selectivity of females and samples. The resulting sample clearly does not reflect the entire population of self employed in Sri Lanka. But it does reflect the population of self employed with less than 100,000 LKR of capital stock. With regard to the analysis in this paper, our main concern is whether the truncation on capital stock results in different selectivity in the female and male sample. Indeed, the data suggest that the sampling criteria eliminated more male then female enterprise owners. This reflects both the fact that males are more likely than females to be self employed in fishing and transportation, and partly this reflects the fact that males have higher levels of invested capital generally. The initial screens eliminated about 42 percent of the male self employed and 20 percent of the female self employed in eligible industries. A further 20 males and 3 females were eliminated when they reported capital stocks in excess of 100,000 LKR at the beginning of the baseline enterprise survey. If ability and capital stock are complements, then the sample will exclude the most able entrepreneurs for both males and females. The more severe truncation for males will result in a more selected sample of males with respect to ability. In particular, if males and females have identical ability distributions in the population of self employed, males in our sample will have lower ability on average than females in our sample. This together with the robustness of the results to inclusion of controls for ability leads us to believe that the empirical patterns discussed in the paper do not result from differential selectivity. 
Table 1: Verification of Randomization by Gender

\begin{tabular}{|c|c|c|c|c|c|c|c|c|}
\hline & \multicolumn{2}{|c|}{$\begin{array}{l}\text { Total number of } \\
\text { observations }\end{array}$} & \multicolumn{3}{|c|}{ Means by treatment: Males } & \multicolumn{3}{|c|}{ Means by treatment: Females } \\
\hline & Male & Female & Control & Treatment & $\begin{array}{l}\text { T-test } \\
\text { p-value }\end{array}$ & Control & Treatment & $\begin{array}{l}\text { T-test } \\
\text { p-value }\end{array}$ \\
\hline Profits March 2005 & 188 & 182 & 4,735 & 4,763 & 0.958 & 2,819 & 2,866 & 0.908 \\
\hline Revenues March 2005 & 197 & 190 & 16,429 & 14,357 & 0.397 & 8,828 & 8,678 & 0.933 \\
\hline Total invested capital March 2005 & 197 & 190 & 153,020 & 176,984 & 0.547 & 112,952 & 143,889 & 0.214 \\
\hline $\begin{array}{l}\text { Total invested capital excluding land } \\
\text { and buildings March } 2005\end{array}$ & 197 & 190 & 33,665 & 29,719 & 0.292 & 20,638 & 20,734 & 0.978 \\
\hline Own hours worked March 2005 & 197 & 190 & 58.37 & 56.83 & 0.613 & 50.28 & 45.75 & 0.168 \\
\hline Family hours worked March 2005 & 197 & 190 & 12.61 & 13.93 & 0.719 & 27.78 & 42.24 & 0.541 \\
\hline Age of entrepreneur & 197 & 190 & 43.52 & 42.17 & 0.427 & 40.26 & 41.78 & 0.340 \\
\hline Age of firm in years & 197 & 188 & 8.99 & 11.15 & 0.172 & 8.08 & 8.79 & 0.631 \\
\hline Years of schooling of entrepreneur & 197 & 190 & 8.20 & 8.65 & 0.308 & 9.79 & 9.19 & 0.182 \\
\hline $\begin{array}{l}\text { Proportion whose father was an } \\
\text { entrepreneur }\end{array}$ & 197 & 190 & 0.44 & 0.42 & 0.764 & 0.37 & 0.32 & 0.501 \\
\hline $\begin{array}{l}\text { Number of household members } \\
\text { working in wage jobs }\end{array}$ & 197 & 190 & 0.54 & 0.57 & 0.817 & 0.87 & 0.89 & 0.840 \\
\hline $\begin{array}{l}\text { Household asset index } \\
\text { Number of Digits recalled in Digit }\end{array}$ & 197 & 190 & 0.25 & 0.03 & 0.347 & 0.60 & 0.28 & 0.169 \\
\hline $\begin{array}{l}\text { Span Recall test } \\
\text { Implied coefficient of relative risk }\end{array}$ & 179 & 178 & 5.86 & 5.90 & 0.833 & 5.61 & 5.74 & 0.512 \\
\hline aversion from lottery game & 197 & 189 & 0.28 & 0.44 & 0.517 & -0.17 & -0.07 & 0.615 \\
\hline P-value from Chi-squared (16) test c & si & nce: & & & 0.652 & & & 0.781 \\
\hline
\end{tabular}


Table 2: Treatment Effect and Returns to Capital with Gender Interactions

\begin{tabular}{|c|c|c|c|c|c|c|}
\hline & $\begin{array}{c}\text { Real } \\
\text { Profits } \\
\text { FE } \\
\text { (1) }\end{array}$ & $\begin{array}{c}\text { Adjusted } \\
\text { Real Profits } \\
\text { FE } \\
\text { (2) }\end{array}$ & $\begin{array}{l}\text { Real } \\
\text { Profits } \\
\text { IV-FE } \\
\\
(3)\end{array}$ & $\begin{array}{l}\text { Adjusted } \\
\text { Real Profits } \\
\text { IV-FE } \\
\text { (4) }\end{array}$ & $\begin{array}{c}\text { Adjusted } \\
\text { Real Profits } \\
\text { FE } \\
\text { MALES } \\
\text { (5) }\end{array}$ & $\begin{array}{c}\text { Adjusted } \\
\text { Real Profits } \\
\text { FE } \\
\text { FEMALES } \\
\text { (6) }\end{array}$ \\
\hline Treatment Amount & $\begin{array}{c}8.04^{\star \star \star} \\
(2.90)\end{array}$ & $\begin{array}{c}7.78^{\star \star \star} \\
(2.81)\end{array}$ & & & & \\
\hline Treatment Amount*Female & $\begin{array}{c}-8.24^{\star *} \\
(4.06)\end{array}$ & $\begin{array}{l}-8.60 * * \\
(3.97)\end{array}$ & & & & \\
\hline Capital Stock & & & $\begin{array}{c}11.29 * * \\
(4.67)\end{array}$ & $\begin{array}{c}11.07^{\star *} \\
(4.53)\end{array}$ & & \\
\hline Capital Stock *Female & & & $\begin{array}{c}-11.39 * \\
(6.17)\end{array}$ & $\begin{array}{l}-12.05^{\star *} \\
(6.03)\end{array}$ & & \\
\hline Treatment* 1-4 quarters post treatment & & & & & $\begin{array}{l}7.75^{\star \star \star} \\
(2.79)\end{array}$ & $\begin{array}{l}-0.91 \\
(2.74)\end{array}$ \\
\hline Treatment* 5-8 quarters post treatment & & & & & $\begin{array}{l}7.84^{* *} \\
(3.78)\end{array}$ & $\begin{array}{l}-0.84 \\
(3.91)\end{array}$ \\
\hline Treatment* $9+$ quarters post treatment & & & & & $\begin{array}{l}7.64^{*} \\
(4.57)\end{array}$ & $\begin{array}{l}-3.24 \\
(4.51)\end{array}$ \\
\hline Observations & 3697 & 3697 & 3518 & 3518 & 1870 & 1827 \\
\hline Number of firms & 365 & 365 & 364 & 364 & 183 & 182 \\
\hline \multicolumn{7}{|c|}{ Testing the overall female effect is zero ( $p$-values) } \\
\hline Amount + Amount ${ }^{\star}$ Female $=0$ & 0.945 & 0.769 & & & & \\
\hline Capital + Capital ${ }^{\star}$ Female $=0$ & & & 0.981 & 0.805 & & \\
\hline \multicolumn{7}{|l|}{ First-stage Coefficients: } \\
\hline $\begin{array}{l}\text { Amount } \\
\text { ( } p \text { value) }\end{array}$ & & & $\begin{array}{c}0.733 \\
0.00\end{array}$ & $\begin{array}{c}0.733 \\
0.00\end{array}$ & & \\
\hline \multicolumn{7}{|l|}{ First-stage for Capital*Female } \\
\hline $\begin{array}{l}\text { Amount*Female } \\
\text { ( } p \text { value) }\end{array}$ & & & $\begin{array}{c}0.697 \\
0.00\end{array}$ & $\begin{array}{c}0.697 \\
0.00\end{array}$ & & \\
\hline
\end{tabular}

Robust Standard errors in parentheses, clustered by enterprise

${ }^{*},{ }^{* *}$ and ${ }^{* *}$ indicate significance at the $10 \%, 5 \%$ and $1 \%$ levels respectively.

Results shown trim firms with extreme increases in profits (top $1 \%$ in percentage and absolute changes)

Adjusted profits are real profits less the value of the owner's time, estimated in six education / gender

cells using a simple production function run on the baseline data. 
Table 3: Do Women invest differently?

\begin{tabular}{|c|c|c|c|c|c|}
\hline & $\begin{array}{c}\text { Capital } \\
\text { Stock } \\
\text { FE } \\
(1) \\
\end{array}$ & $\begin{array}{c}\text { Capital } \\
\text { Stock } \\
\\
\text { FE } \\
(2) \\
\end{array}$ & $\begin{array}{c}\text { Adjusted } \\
\text { profits } \\
\text { FE } \\
(3)\end{array}$ & $\begin{array}{c}\text { Adjusted } \\
\text { profits } \\
\text { Males } \\
\text { FE } \\
(4) \\
\end{array}$ & $\begin{array}{c}\text { Adjusted } \\
\text { profits } \\
\text { Females } \\
\text { FE } \\
\text { (5) }\end{array}$ \\
\hline Treatment Amount 100 & $\begin{array}{l}1.38^{\star \star} \\
(0.649)\end{array}$ & $\begin{array}{l}0.63^{\star} \\
(0.317)\end{array}$ & $\begin{array}{c}13.58^{\star \star \star} \\
(3.70)\end{array}$ & & \\
\hline Amount 100 * Female & $\begin{array}{c}-1.39^{* *} \\
(0.708)\end{array}$ & $\begin{array}{l}-0.41 \\
(0.402)\end{array}$ & $\begin{array}{c}-14.15^{\star \star \star} \\
(5.25)\end{array}$ & & \\
\hline Treatment Amount 200 & $\begin{array}{l}1.22^{\star \star \star} \\
(0.430)\end{array}$ & $\begin{array}{l}1.43^{\star \star \star} \\
(0.386)\end{array}$ & $\begin{array}{c}12.95^{\star \star \star} \\
(4.06)\end{array}$ & & \\
\hline Amount 200 * Female & $\begin{array}{l}0.475 \\
(0.777)\end{array}$ & $\begin{array}{l}-0.46 \\
(0.758)\end{array}$ & $\begin{array}{c}-14.83^{\star \star} \\
(6.46)\end{array}$ & & \\
\hline Amount * \% inventories & & & & $\begin{array}{c}8.53^{\star *} \\
(3.35)\end{array}$ & $\begin{array}{l}1.39 \\
(4.39)\end{array}$ \\
\hline Amount* \% equipment & & & & $\begin{array}{c}5.3 \\
(6.53)\end{array}$ & $\begin{array}{l}-5.8 \\
(5.88)\end{array}$ \\
\hline Observations & 3519 & 1135 & 3697 & 1772 & 1775 \\
\hline Number of Firms & 365 & 365 & 365 & 173 & 176 \\
\hline
\end{tabular}

Notes:

Robust Standard errors in parentheses, clustered by enterprise

${ }^{*}, * *$ and ${ }^{* * *}$ indicate significance at the $10 \%, 5 \%$ and $1 \%$ levels respectively.

The sample in Column 2 is limited to controls and the first wave after treatment

Adjusted profits are real profits less the value of the owner's time, estimated in six education / gender cells using a simple production function run on the baseline data. 
Table 4: Do Women invest less in the business and more on children?

\begin{tabular}{|c|c|c|c|c|c|c|c|}
\hline & \multicolumn{3}{|c|}{ School Attendance } & \multicolumn{3}{|c|}{ Monthly Household Expenditure } & \multirow{2}{*}{$\begin{array}{c}\text { Index } \\
\text { Household } \\
\text { assets }\end{array}$} \\
\hline & 5 to 12 & 12 to 15 & 17 to 18 & Groceries & Health & Education & \\
\hline & FE & FE & FE & FE & FE & FE & FE \\
\hline & (1) & $(2)$ & (3) & (4) & (5) & (6) & (7) \\
\hline Treatment Amount & $\begin{array}{c}-0.0310 \\
-(0.060)\end{array}$ & $\begin{array}{c}-0.0110 \\
(0.062)\end{array}$ & $\begin{array}{c}-0.0050 \\
(0.113)\end{array}$ & $\begin{array}{l}-5.00 \\
(5.63)\end{array}$ & $\begin{array}{l}-0.56 \\
(1.40)\end{array}$ & $\begin{array}{l}-0.11 \\
(0.75)\end{array}$ & $\begin{array}{l}0.282^{\star *} \\
-(0.110)\end{array}$ \\
\hline Amount*Female & $\begin{array}{c}-0.0120 \\
(0.081)\end{array}$ & $\begin{array}{c}0.0218 \\
(0.081)\end{array}$ & $\begin{array}{c}0.1230 \\
(0.148)\end{array}$ & $\begin{array}{l}10.50 \\
(8.64)\end{array}$ & $\begin{array}{l}0.40 \\
(1.83)\end{array}$ & $\begin{array}{l}-0.27 \\
(0.98)\end{array}$ & $\begin{array}{c}-0.259^{\star} \\
-(0.148)\end{array}$ \\
\hline $\begin{array}{l}\text { Baseline mean of dependent } \\
\text { variable }\end{array}$ & 0.923 & 0.915 & 0.533 & 6810 & 678 & 474 & 0 \\
\hline Observations & 605 & 433 & 272 & 1328 & 1328 & 1328 & 1393 \\
\hline Number of Firms & 210 & 158 & 135 & 361 & 361 & 361 & 365 \\
\hline
\end{tabular}

Notes:

Robust Standard errors in parentheses, clustered by enterprise

*, ** and ${ }^{* \star *}$ indicate significance at the $10 \%, 5 \%$ and $1 \%$ levels respectively.

Data from household module conducted each April from 2005 through 2008.

Household asset index is the first principal component of 19 household 17 household assets. 
Table 5: Household bargaining

\begin{tabular}{|c|c|c|c|c|c|}
\hline & $\begin{array}{l}\text { Household } \\
\text { decision } \\
\text { making }\end{array}$ & $\begin{array}{l}\text { Business } \\
\text { decision } \\
\text { making }\end{array}$ & $\begin{array}{l}\text { Hours worked } \\
\text { by other } \\
\text { family }\end{array}$ & $\begin{array}{l}\text { No children, } \\
\text { no elderly }\end{array}$ & $\begin{array}{l}\text { Spouse } \\
\text { Present at } \\
\text { Interview }\end{array}$ \\
\hline & \multicolumn{2}{|c|}{ Adjusted Profits } & & \multicolumn{2}{|c|}{ Adjusted Profits } \\
\hline & FE & FE & FE & FE & FE \\
\hline & (2) & (3) & (4) & (5) & (1) \\
\hline \multirow[t]{2}{*}{ Treatment Amount } & $8.01^{\star \star \star}$ & $8.41^{\star \star \star}$ & 0.44 & 7.60 & $7.77^{\star \star \star}$ \\
\hline & $(3.11)$ & $(2.99)$ & (1.26) & $(4.50)$ & $(2.83)$ \\
\hline \multirow[t]{2}{*}{ Amount*Female } & -8.14 & $-8.62^{\star *}$ & -2.09 & -8.93 & $-8.53^{\star *}$ \\
\hline & $(4.47)$ & $(4.24)$ & $(4.96)$ & (5.93) & $(3.97)$ \\
\hline Spouse present at interview & & & & & $\begin{array}{l}-4.33^{*} \\
(2.33)\end{array}$ \\
\hline \multirow[t]{2}{*}{ Spouse present* female } & & & & & 2.17 \\
\hline & & & & & $(2.75)$ \\
\hline \multirow{2}{*}{$\begin{array}{l}\text { Decision making power in household } \\
\text { / business }\end{array}$} & -0.85 & -1.40 & & & \\
\hline & $(1.76)$ & $(1.48)$ & & & \\
\hline Observations & 3486 & 3486 & 3799 & 1534 & 3697 \\
\hline Number of Firms & 332 & 332 & 365 & 152 & 365 \\
\hline \multicolumn{6}{|l|}{ Notes: } \\
\hline \multirow{2}{*}{\multicolumn{6}{|c|}{$\begin{array}{l}\text { Robust Standard errors in parentheses, clustered by enterprise } \\
*^{* *} \text { and }{ }^{* \star} \text { indicate significance at the } 10 \%, 5 \% \text { and } 1 \% \text { levels }\end{array}$}} \\
\hline & & & & & \\
\hline \multicolumn{6}{|c|}{$\begin{array}{l}\text { Decision making power in the household is measured as the sum of } 4 \text { purchase decisions in which the owner } \\
\text { is involved. Decision making power in the business indicates the owner makes input and equipment purchase } \\
\text { decisions without input from his/her spouse. }\end{array}$} \\
\hline
\end{tabular}

Table 6: How do the characteristics of male and female owners differ?

\begin{tabular}{lccc}
\hline & \multicolumn{2}{c}{ Mean value } & T-test \\
& Males & Females & p value \\
\hline Ever had a formal loan & 0.23 & 0.23 & 0.99 \\
Number of Wage Workers & 0.55 & 0.87 & 0.00 \\
Asset Index & -0.20 & 0.20 & 0.04 \\
Years of Education & 8.57 & 9.41 & 0.01 \\
Digitspan Recall & 5.88 & 5.61 & 0.06 \\
Entrepreneurial Self-efficacy & 31.51 & 30.79 & 0.22 \\
Polychronicity & 7.76 & 7.32 & 0.06 \\
In Self-employment to care for children & 0.40 & 0.49 & 0.09 \\
In Self-employment for business growth & 0.31 & 0.35 & 0.55 \\
Risk Aversion & 0.37 & -0.07 & 0.01 \\
\hline
\end{tabular}


Table 7: Does treatment heterogeneity explain gender differences? Dependent Variable: Real profits adjusted for own hours

\begin{tabular}{|c|c|c|c|c|c|c|c|c|}
\hline & $\begin{array}{l}\text { FE } \\
(1) \\
\end{array}$ & $\begin{array}{l}\text { FE } \\
(2) \\
\end{array}$ & $\begin{array}{l}\text { FE } \\
(3)\end{array}$ & $\begin{array}{l}\text { FE } \\
(4) \\
\end{array}$ & $\begin{array}{l}\text { FE } \\
(5) \\
\end{array}$ & $\begin{array}{l}\text { FE } \\
(6) \\
\end{array}$ & $\begin{array}{l}\text { FE } \\
(7) \\
\end{array}$ & $\begin{array}{l}\text { FE } \\
(8)\end{array}$ \\
\hline Amount & $\begin{array}{c}\text { 7.78*** }^{\text {(2.81) }} \\
\text { (2.8 }\end{array}$ & $\begin{array}{c}\mathbf{7 . 8 6}^{\star \star * *} \\
(2.87)\end{array}$ & $\begin{array}{c}7.07^{\star *} \\
(2.82)\end{array}$ & $\begin{array}{c}\text { 7.38*** } \\
(2.83)\end{array}$ & $\begin{array}{c}7.88^{\star \star \star} \\
(2.77)\end{array}$ & $\begin{array}{c}\text { 7.41** }^{*} \\
(2.89)\end{array}$ & $\begin{array}{c}\text { 7.90*** } \\
(2.90)\end{array}$ & $\begin{array}{r}6.77^{\star \star} \\
(2.95)\end{array}$ \\
\hline Amount*Female & $\begin{array}{c}-8.60 * \star \\
(3.97)\end{array}$ & $\begin{array}{c}-8.54^{\star *} \\
(4.00)\end{array}$ & $\begin{array}{r}-7.40^{*} \\
(4.17)\end{array}$ & $\begin{array}{c}-7.75^{\star \star} \\
(3.86)\end{array}$ & $\begin{array}{c}-8.35^{\star *} \\
(3.95)\end{array}$ & $\begin{array}{l}-7.62^{*} \\
(4.04)\end{array}$ & $\begin{array}{c}-8.92^{\star *} \\
(3.99)\end{array}$ & $\begin{array}{l}-6.09 \\
(4.24)\end{array}$ \\
\hline Amount`Ever had a formal loan & & $\begin{array}{l}-7.85 \\
(5.76)\end{array}$ & & & & & & $\begin{array}{l}-8.82 \\
(5.66)\end{array}$ \\
\hline Amount*Number of Wage Workers & & & $\begin{array}{l}-3.16 \\
(2.46)\end{array}$ & & & & & $\begin{array}{l}-1.86 \\
(2.48)\end{array}$ \\
\hline Amount*Household Asset Index & & & & $\begin{array}{l}-1.81 \\
(1.16)\end{array}$ & & & & $\begin{array}{c}-2.82^{\star *} \\
(1.17)\end{array}$ \\
\hline Amount ${ }^{\star}$ Years of Education & & & & & $\begin{array}{c}1.18^{\star \star} \\
(0.49)\end{array}$ & & & $\begin{array}{c}1.61^{\star \star \star} \\
(0.56)\end{array}$ \\
\hline Amount*Digitspan recall & & & & & & $\begin{array}{l}2.62 \\
(1.66)\end{array}$ & & $\begin{array}{l}1.42 \\
(1.56)\end{array}$ \\
\hline Amount* Risk aversion & & & & & & & $\begin{array}{l}-0.61 \\
(1.14)\end{array}$ & $\begin{array}{c}-0.13 \\
(114.00)\end{array}$ \\
\hline Observations & 3697 & 3697 & 3697 & 3697 & 3697 & 3655 & 3697 & 3655 \\
\hline Number of enterprises & 365 & 365 & 365 & 365 & 365 & 356 & 365 & 356 \\
\hline
\end{tabular}

Robust Standard errors in parentheses, ${ }^{*},{ }^{* *}$ and ${ }^{* * *}$ indicate significance at the $10 \%, 5 \%$ and $1 \%$ levels respectively.

All variables used in the interaction apart from gender are standardized to have mean zero by subtracting off their mean. 
Table 8: Robustness of Gender Interaction to Alternative Measures of Ability and Motivation

\begin{tabular}{|c|c|c|c|c|c|c|}
\hline \multirow{3}{*}{$\begin{array}{l}\text { Characteristic } \\
\text { Baseline Specification }\end{array}$} & \multirow{2}{*}{\multicolumn{2}{|c|}{ Amount }} & \multirow{2}{*}{\multicolumn{2}{|c|}{$\begin{array}{l}\text { Amount* } \\
\text { Female }\end{array}$}} & \multirow{3}{*}{$\begin{array}{c}\text { Amount* }^{*} \\
\text { Characteristic }\end{array}$} & \multirow{3}{*}{$\begin{array}{c}\mathbf{N} \\
324\end{array}$} \\
\hline & & & & & & \\
\hline & $\begin{array}{c}651.5 \\
(241)\end{array}$ & $\star * *$ & $\begin{array}{c}-750.6 \\
(373)\end{array}$ & ** & & \\
\hline \multicolumn{7}{|c|}{ Adding the interaction between amount and: } \\
\hline Time taken to solve a maze & $\begin{array}{l}8.13 \\
(2.81)\end{array}$ & $\star \star \star *$ & $\begin{array}{l}-9.16 \\
(4.06)\end{array}$ & ** & $\begin{array}{l}0.07 \\
(4.52)\end{array}$ & 363 \\
\hline Father owned a Business & $\begin{array}{l}7.60 \\
(2.89)\end{array}$ & $\star \star \star *$ & $\begin{array}{l}-8.20 \\
(3.95)\end{array}$ & ** & $\begin{array}{l}3.64 \\
3.77\end{array}$ & 365 \\
\hline Mother owned a Business & $\begin{array}{l}7.64 \\
(2.87)\end{array}$ & $\star * \star$ & $\begin{array}{l}-8.44 \\
(3.97)\end{array}$ & ** & $\begin{array}{l}-1.40 \\
(5.49)\end{array}$ & 365 \\
\hline Optimism & $\begin{array}{l}7.95 \\
(2.76)\end{array}$ & $\star \star \star *$ & $\begin{array}{l}-8.64 \\
(3.95)\end{array}$ & ** & $\begin{array}{l}0.38 \\
(1.37)\end{array}$ & 364 \\
\hline $\begin{array}{l}\text { Went into self-employment to } \\
\text { care for family members }\end{array}$ & $\begin{array}{l}8.05 \\
(2.87)\end{array}$ & $\star \star \star *$ & $\begin{array}{l}-9.26 \\
(4.13)\end{array}$ & ** & $\begin{array}{l}0.82 \\
(1.30)\end{array}$ & 353 \\
\hline $\begin{array}{l}\text { Went into Self-employment for } \\
\text { business growth reasons }\end{array}$ & $\begin{array}{l}7.81 \\
(2.93)\end{array}$ & $* \star *$ & $\begin{array}{l}-8.76 \\
(4.07)\end{array}$ & ** & $\begin{array}{l}1.43 \\
(4.14)\end{array}$ & 353 \\
\hline Business operated out of the hon & $\begin{array}{l}7.84 \\
(2.84)\end{array}$ & *** & $\begin{array}{l}-8.89 \\
(4.04)\end{array}$ & ** & $\begin{array}{l}2.80 \\
(4.03)\end{array}$ & 365 \\
\hline Entrepreneurial Self-efficacy & $\begin{array}{l}8.06 \\
(2.95)\end{array}$ & $\star \star \star *$ & $\begin{array}{l}-9.59 \\
(4.24)\end{array}$ & ** & $\begin{array}{l}-0.54 \\
(0.36)\end{array}$ & 354 \\
\hline Financial Literacy & $\begin{array}{l}7.30 \\
(2.76)\end{array}$ & $* \star *$ & $\begin{array}{l}-8.08 \\
(4.02)\end{array}$ & ** & $\begin{array}{l}0.25 \\
(1.90)\end{array}$ & 365 \\
\hline Impulsiveness & $\begin{array}{l}7.20 \\
(2.93)\end{array}$ & $* *$ & $\begin{array}{l}-8.32 \\
(4.21)\end{array}$ & ** & $\begin{array}{l}-0.31 \\
(1.30)\end{array}$ & 339 \\
\hline Passion for Work & $\begin{array}{l}7.24 \\
(2.91)\end{array}$ & $* *$ & $\begin{array}{l}-7.45 \\
(4.26)\end{array}$ & * & $\begin{array}{l}2.22 \\
(2.98)\end{array}$ & 339 \\
\hline Tenacity & $\begin{array}{l}7.55 \\
(2.90)\end{array}$ & $* \star *$ & $\begin{array}{l}-8.61 \\
(4.10)\end{array}$ & ** & $\begin{array}{l}-0.98 \\
(2.00)\end{array}$ & 339 \\
\hline Locus of Control & $\begin{array}{l}7.85 \\
(2.96)\end{array}$ & $* * *$ & $\begin{array}{l}-8.72 \\
(4.29)\end{array}$ & ** & $\begin{array}{l}-0.25 \\
(0.97)\end{array}$ & 339 \\
\hline Trust & $\begin{array}{l}7.76 \\
(2.96)\end{array}$ & $* \star *$ & $\begin{array}{l}-8.20 \\
(4.10)\end{array}$ & ** & $\begin{array}{l}1.63 \\
(2.38)\end{array}$ & 339 \\
\hline Achievement Motivation & $\begin{array}{l}7.61 \\
(2.96)\end{array}$ & $* *$ & $\begin{array}{l}-8.14 \\
(4.24)\end{array}$ & * & $\begin{array}{c}-0.16 \\
(0.89)\end{array}$ & 339 \\
\hline Power Motivation & $\begin{array}{l}7.80 \\
(3.04)\end{array}$ & $* *$ & $\begin{array}{l}-8.36 \\
(4.30)\end{array}$ & * & $\begin{array}{l}0.05 \\
(1.10)\end{array}$ & 339 \\
\hline Polychronicity & $\begin{array}{l}7.43 \\
(2.95)\end{array}$ & $\star *$ & $\begin{array}{l}-8.07 \\
(4.18)\end{array}$ & * & $\begin{array}{l}0.68 \\
(0.89)\end{array}$ & 339 \\
\hline Work Centrality & $\begin{array}{l}7.38 \\
(2.96)\end{array}$ & $* *$ & $\begin{array}{l}-8.10 \\
(4.17)\end{array}$ & * & $\begin{array}{c}-1.82 \\
(2.34)\end{array}$ & 339 \\
\hline Organized Person & $\begin{array}{l}7.88 \\
(2.94)\end{array}$ & $* \star *$ & $\begin{array}{l}-8.33 \\
(4.21)\end{array}$ & ** & $\begin{array}{l}-2.83 \\
(3.66)\end{array}$ & 339 \\
\hline
\end{tabular}

Notes: Results in Rows show the coefficients from adding the interaction between a particular proxy for ability and the treatment amount to the baseline specification (column 1 of Table 7). Regressions also include the interaction between this characteristics and wave effects.

Robust Standard errors shown in Parentheses, * , **, and *** interact significance at the 10, 5 and 1\% levels. 
Table 9: Do Differences in Sector of Work explain Gender Differences?

Dependent Variable: Real profits adjusted for own hours worked

\begin{tabular}{lcccc}
\hline & All Firms & All Firms & $\begin{array}{c}\text { Only industries with } \\
\text { participation from } \\
\text { both genders above } \\
25 \%\end{array}$ & $\begin{array}{c}\text { Only industries with } \\
\text { participation below } \\
25 \% \text { from one gender }\end{array}$ \\
\hline Panel A: Treatment effect & & & & \\
Amount & $6.91^{\star \star}$ & $5.91^{\star}$ & $8.28^{\star *}$ & $7.64^{\star}$ \\
Amount*Female & $(2.72)$ & $(3.58)$ & $(4.16)$ & $(3.91)$ \\
& $-7.51^{\star}$ & $-9.48^{\star *}$ & -7.83 & $-13.86^{\star}$ \\
Obs. & $(3.92)$ & $(3.77)$ & $(4.96)$ & $(7.11)$ \\
Firms & 3722 & 3697 & 1994 & 1703 \\
& 365 & 365 & 196 & 169
\end{tabular}

Panel B: Returns to Capital

$\begin{array}{lcccc}\text { Capital Stock } & 10.06^{\star *} & 9.63 & 13.67^{\star} & 9.54 \\ & (4.33) & (6.12) & (7.54) & (5.81) \\ \text { Capital Stock*Female } & -10.71^{\star} & -13.34^{\star *} & -12.8 & -18.01^{\star} \\ & (5.87) & (6.62) & (8.59) & (8.71) \\ & & & & \\ \text { Obs. } & 3541 & 3518 & 1944 & 1574 \\ \text { Firms } & 364 & 364 & 196 & 168 \\ & & & & \text { no } \\ \text { Industry*Wave effects } & \text { no } & \text { yes } & \text { no } & \text { no } \\ \text { Industry*Amount controls } & \text { no } & \text { yes } & \text { no } & \end{array}$

Robust Standard errors in parentheses, ${ }^{*},{ }^{* \star}$ and ${ }^{* \star \star}$ indicate significance at the $10 \%, 5 \%$ and $1 \%$ levels respectively.

Column 2 include 8 industry dummies and 80 industry ${ }^{\star}$ wave dummies. The samples in Columns (3)

and (4) are restricted using the distribution of male and female ownership in 20 industries with more

than 4 enterprises in the sample. 
Table 10: Do the results generalize to other countries?

Dependent Variable: Monthly Microenterprise Profits (US dollars)

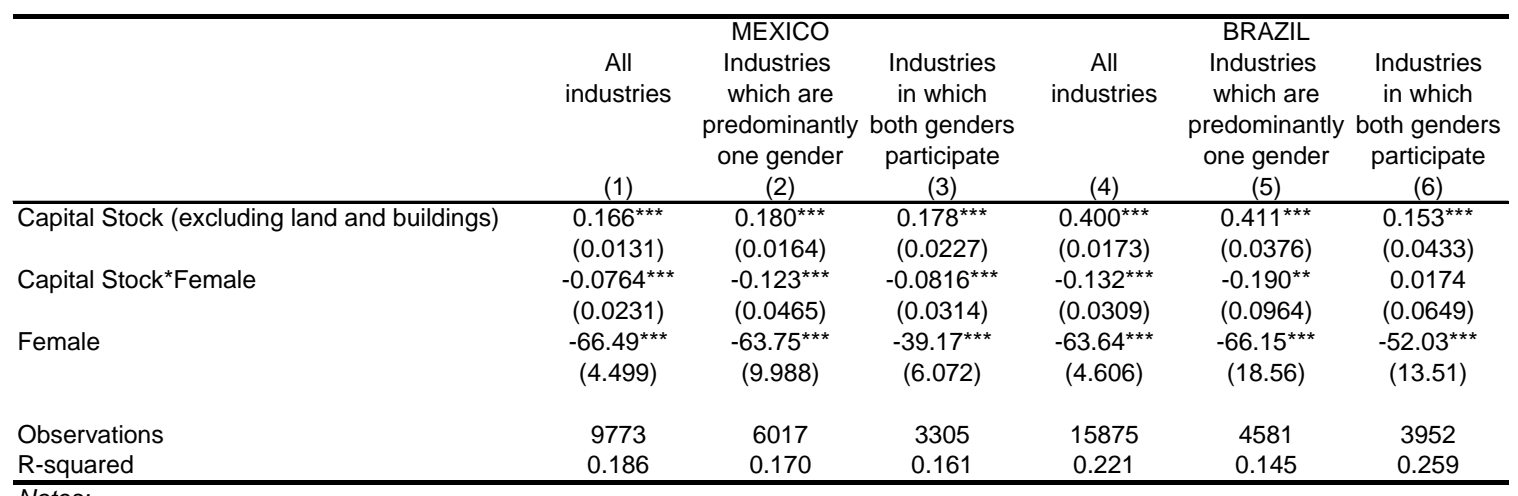

Notes:

Robust standard errors in parentheses, ${ }^{* *} \mathrm{p}<0.01,{ }^{* *} \mathrm{p}<0.05,{ }^{*} \mathrm{p}<0.1$

All regressions also include controls for age and education of the owner and own hours worked.

Mexico regressions also include year of survey dummies.

Industry subsamples in (2) and (5) are industries which are either less than $25 \%$ female, or more than $75 \%$ female

Industry subsamples in (3) and (6) are industries which are between $26 \%$ and $74 \%$ female.

Industry subsamples restricted to industries with at least 50 firms in the sample. 
Table 11: Heterogeneity of Returns Amongst Female-Owned Enterprises

Dependent Variable: Real profits adjusted for own hours worked

\begin{tabular}{|c|c|c|c|c|}
\hline & $\begin{array}{l}\text { FE } \\
(1) \\
\end{array}$ & $\begin{array}{l}\text { FE } \\
(2) \\
\end{array}$ & $\begin{array}{l}\text { FE } \\
(3) \\
\end{array}$ & $\begin{array}{l}\text { FE } \\
(4) \\
\end{array}$ \\
\hline Amount & $\begin{array}{l}-0.82 \\
(2.80)\end{array}$ & $\begin{array}{l}-0.81 \\
(2.87)\end{array}$ & $\begin{array}{l}1.00 \\
(2.58)\end{array}$ & $\begin{array}{l}\mathbf{0 . 8 1} \\
(2.44)\end{array}$ \\
\hline Amount*Ever had formal loan & & & & $\begin{array}{l}-1.18 \\
(6.63)\end{array}$ \\
\hline Amount*Number of Wage Workers & & & & $\begin{array}{l}1.39 \\
(3.26)\end{array}$ \\
\hline Amount*Household Asset Index & & & & $\begin{array}{c}-2.95 * \\
(1.51)\end{array}$ \\
\hline Amount*Years of Education & & $\begin{array}{l}0.55 \\
(0.81)\end{array}$ & & $\begin{array}{l}0.08 \\
0.91\end{array}$ \\
\hline Amount*Digitspan recall & & & $\begin{array}{c}6.41^{\star \star \star} \\
(1.89)\end{array}$ & $\begin{array}{c}6.89 * \star * \\
(2.33)\end{array}$ \\
\hline Amount*Risk aversion & & & & $\begin{array}{l}-0.61 \\
(1.66)\end{array}$ \\
\hline Observations & 1827 & 1827 & 1805 & 1805 \\
\hline Number of enterprises & 182 & 182 & 177 & 177 \\
\hline$\%$ with mean treatment less than or equal to 0 & & 47.9 & 48.3 & 59.0 \\
\hline$\%$ with mean treatment between 0 and 200 & & 51.6 & 10.1 & 5.0 \\
\hline$\%$ with mean treatment between 200 and 500 & & 0.5 & 19.6 & 9.0 \\
\hline$\%$ with mean treatment of more than 500 & & 0.0 & 22.0 & 27.0 \\
\hline
\end{tabular}

Notes:

Robust Standard errors in parentheses, *, ** and *** indicate significance at the $10 \%, 5 \%$ and $1 \%$ levels respectively.

All variables used in the interaction apart from gender are standardized to have mean zero by subtracting off their mean. 